\title{
LOCAL SALES TAX OPTIONS: A CASE STUDY OF SOUTH GEORGIA
}

\author{
J. L. Love*
}

\begin{abstract}
This study examines the impact of sales tax differentials on taxable sales in rural south Georgia during 1980-89, using a cell-mean corrected regression model. Results indicate that sales tax rate differentials have a significant effect on urban counties' taxable sales. The level of impact on taxable sales, as measured by its elasticity coefficient, is influenced by the shopping characteristics of the area. A greater number of service and retail establishments tends to lessen the impact of a tax differential as search costs are reduced; nearby shopping alternatives increase the effect as travel costs are reduced. The impact of creating a sales tax differential appears to depend on the shopping attributes of the region relative to its competing areas. In a rural environment where shopping patterns are established and consumers lack convenient shopping altematives, regional shopping centers have the potential to shift or export part of their tax burden without causing significant loss to their retail trading base.
\end{abstract}

\section{INTRODUCTION}

Most city and county governments experience the continuing problem of increasing their revenues to satisfy expanding expenditure demands. One of the responses by local governments is an increased reliance on local sales taxes. The use of local sales tax (LST) options has expanded rapidly. By 1987, 30 states permitted their local governments to impose a local tax, usually on an urban basis; however, six states provided for countywide jurisdiction (Fisher 1988, 174). Frequently, local governments base their actions on the assumption that tax revenues will increase in the same proportion as the increase in the tax rate. This assumption implies that local sales will not be reduced by the increase in the tax rate. However, rational action on the part of the consumer implies that a tax rate increase that causes a tax rate differential between neighboring areas may provide an incentive for consumers to substitute purchases in the lower tax jurisdiction for purchases in the higher tax jurisdiction.

Since the sales tax is levied on retail sales, its effects are of interest to the imposing jurisdiction's business community as well as to government policymakers. Previous research on this subject (Mikesell 1970; Fisher 1980; Walsh and Jones 1988; Snodgrass and Otto 1990) examined the effects of sales tax rate differentials between neighboring tax jurisdictions.

*Associate Professor of Economics, Valdosta State College. 
Mikesell (1970) examined 173 SMSA central cities' retail sales for 1963. Mikesell found that a one-point increase in the central city tax rate relative to the suburban tax rate resulted in a 1.7 percent to 11 percent reduction in per capita sales in the central city. In addition, he found that the larger the area, the lower the per capita sales, which implies that travel in larger cities is more costly. Thus, suburban residents are less inclined to take advantage of the lower sales tax rate in the central city. Fisher (1980) examined food sales in the District of Columbia and found that sales declined seven points for each one percentage point increase in the tax differential between the district and its neighbors.

Wash and Jones (1988) used countywide panel data to examine the effects of a tax differential between West Virginia counties and border county retail sales. They found that a tax differential provided an effective incentive to consumers in the higher tax counties to cross state boundaries to take advantage of the lower tax rate.

Snodgrass and Otto (1990) studied the effects of tax rates and tax rate differentials on local sales tax revenues in rural Oklahoma. Their study included 75 nonmetropolitan cities with populations between 2,500 and 42,500. They found a positive and statistically significant coefficient on the sales tax rate, indicating that sales tax revenues increase with increases in the tax rate.

The purpose of this paper is to examine the effects of sales tax rate differentials on the levels of taxable sales in nonmetropolitan counties in south Georgia. A pooled sample of annual times series and cross-sectional data over 1980-89 is used to examine the impact on county per capita taxable sales to changes in the sales tax rate while controlling for changes in local shopping characteristics that may influence consumers. The remainder of paper is divided into four sections: Definition of Regions, where the delineation of regions is discussed; Empirical Model, which explains the model used in the study; Empirical Results and Data, which reports the findings of the model and data sources; and Conclusions.

\section{DEFINITION OF REGIONS}

Since the study is interested in the effects of sales tax differentials on retail sales, cities that provide intercounty shopping facilities were sought. Observations were limited to the urban areas in south Georgia with populations between 10,000 and $50,000 .{ }^{1}$ It is assumed that urban areas that have populations of less than 10,000 do not possess the necessary attractions to be a shopping center for their neighboring counties. A comparison of county per capita sales supports this assumption; counties with cities of 10,000 or more have sales per person twice as high as counties without such cities. This definition of urban counties (counties 
that contain a city with a population between 10,000 and 50,000 ) provides a sample of 16 separate areas (see Figure 1), over a ten year period, 1980-89 for a total of 160 observations. The cities in the urban counties range in population from 10,000 to 36,000 , with an average population of $16,000 .^{2}$

Georgia has two local sales tax options: local county option and special county option. A county can impose either or both of the tax options at a rate of 1 percent each for a maximum rate above the state of 2 percent. The local county option sales tax is designed to fund normal governmental operations and is imposed for an indefinite period. The special option is imposed for a specific period of time and for a specific project; therefore, a county's sales tax rate may increase or decrease over the time span. The local county option began in Georgia in 1972 with the introduction of a special transit tax in Atlanta. The local county option was extended to the rest of the state in 1976, and the Special County Option in 1986. The use of these taxes is not uniform across the state; in 1980, only 53 percent of the counties imposed a 1 percent tax, and by 1989, less than half imposed the full 2 percent.

In Georgia, these local sales tax options are imposed on a countywide basis; therefore, the county is the basis of the analysis. The shopping area boundary of the urban county is defined as its contiguous counties. This specification of urbancounty shopping areas causes some overlapping of counties where urban counties are contiguous, or their shopping area contains some of the same counties. This overlapping does not create a problem for the analysis because it allows competition between urban counties.

\section{EMPIRICAL MODEL}

The taxable sales model is comparable to previous studies that have examined the effects of explanatory variables on retail sales (Walsh and Jones 1988; Mikesell 1970) and on tax revenues (Snodgrass and Otto 1990; Fisher 1980). It is assumed that per capita taxable sales in region i depends on the aftertax price of goods in county i relative to that of its contiguous counties, per capita income in region $i$, the attractiveness of county $i$ as a shopping center, and the cost of travel from the contiguous counties to county $i$. The model of taxable sales used in the study is similar to the model employed by Walsh and Jones (1988). However, an additive demand model was found to fit the data better than the multiplicative models used in pervious studies as shown in Equation (1). 
FIGURE 1

State of Georgia

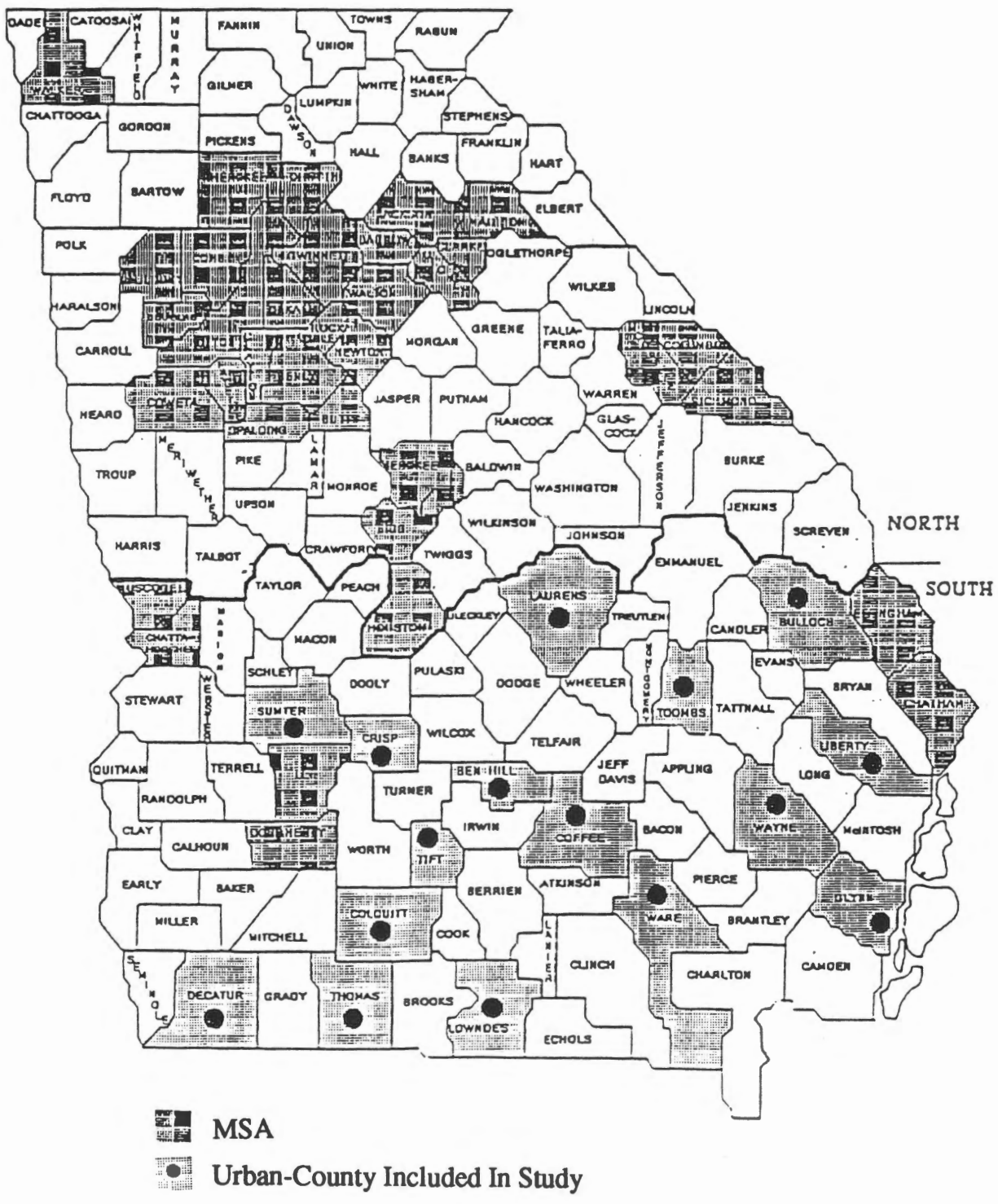




$$
\begin{array}{ll}
\mathrm{SPC}_{\mathrm{it}}= & \begin{array}{l}
\mathrm{F}\left(\mathrm{TD}_{\mathrm{ijt}}, \mathrm{PCPI}_{\mathrm{it}}, \mathrm{SRNP}_{\mathrm{it}}, \mathrm{MA}_{\mathrm{ijt}}\right) . \\
\mathrm{i}, \mathrm{j}=1, \ldots, 16 \quad \mathrm{t}=1, \ldots, 10(1980-89)
\end{array} \\
\mathrm{SPC}_{\mathrm{it}}= & \begin{array}{l}
\text { per capita taxable sales, deflated by the consumer } \\
\text { price index, in county } \mathrm{i} \text { at time } \mathrm{t} .
\end{array} \\
\mathrm{TD}_{\mathrm{ijt}}=\quad \begin{array}{l}
\text { the sales tax differntials between county } \mathrm{i} \text { at time } \\
\mathrm{t} \text { and its contiguous counties, } \mathrm{j} . \text { Formulation } \\
\text { of the tax differential coefficient follows that set out } \\
\text { by Mikesell (1970): }
\end{array}
\end{array}
$$

$$
T D_{i j t}=\frac{\sum_{j} \frac{1+T R_{i t}}{1+T R_{j t}} P I_{j t}}{\sum_{j} P I_{j t}},
$$

where:

$$
\begin{aligned}
\mathrm{TD}_{\mathrm{ijt}}= & \text { the personal income weighted tax differential } \\
& \text { coefficient for county } \mathrm{i} \text { relative to county } \mathrm{j} \text { at time } \mathrm{t} . \\
\mathrm{TR}_{\mathrm{it}} \text { and } \mathrm{TR}_{\mathrm{jt}}= & \text { the sales tax rates of county } \mathrm{i} \text { and its contiguous } \\
& \text { counties } \mathrm{j}, \text { respectively. } \\
\mathrm{PI}_{\mathrm{jt}}= & \text { personal income in contiguous county } \mathrm{j} . \\
\mathrm{PCPI}_{\mathrm{it}}= & \text { real per capita personal income in county } \mathrm{i} \\
& \text { at time } \mathrm{t} . \\
\mathrm{SRNP}_{\mathrm{it}}= & \text { the number of retail and service establishments per } \\
& \text { capita in county } \mathrm{i} \text { at time t. } \\
\mathrm{MA}_{\mathrm{ijt}}= & \text { the retail market area. The variable is derived } \\
& \text { from the average distance of the ith county's } \\
& \text { shopping boundaries relative to its surrounding } \\
& \text { cities using Reilly's Law of Retail Gravitational } \\
& \text { Attraction: }
\end{aligned}
$$

$A D_{i j}$ is the average distance to the shopping boundary between cities.

Taxable sales per capita (SPC $\left.{ }_{i t}\right)$ are expected to vary inversely with the sales tax differential variable ( $T \mathrm{D}_{\mathrm{ij}}$ ) as consumers respond to the lower aftertax price in 
the contiguous counties. Implicit in the model are the assumptions that the cost of inputs is equal in both areas, and that the long-term supply curve reflects a constant cost industry. These assumptions are the standard method for dealing with the boarder tax issue. Per capita personal income in county $\mathrm{i}\left(\mathrm{PCPI}_{\mathrm{it}}\right)$ is expected to be directly related to per capita taxable sales. The number of service and retail establishments per capita in county $\mathrm{i}\left(\mathrm{SRN}_{\mathrm{it}}\right)$ is expected to be directly related to per capita sales because this variable is a proxy for the attractiveness of the county as a shopping area. The number of shops in the area represents the attraction to consumers of a greater selection, which would tend to lower their search costs and increase sales in the county. The market area of urban county $\mathrm{i}\left(\mathrm{MA}_{\mathrm{ijt}}\right)$ reflects the distance and attraction of competing urban counties. The market area variable is expected to be inversely related to per capita taxable sales because a greater market area implies a greater cost of travel to the consumer.

\section{EMPIRICAL RESULTS AND DATA}

The equation estimated is derived from Equation (1) by calculating the cell mean and adding an error term. The results are presented as Equation (2).

$$
\operatorname{DSPC}_{\mathrm{it}}=\beta_{\mathrm{o}}+\beta_{1} \mathrm{DTD}_{\mathrm{ijt}}+\beta_{2} \mathrm{DPCPI}_{\mathrm{it}}+\beta_{3} \mathrm{DSRN}_{\mathrm{it}}+\beta_{4} \mathrm{MA}_{\mathrm{ijt}}+\mathrm{u}_{\mathrm{it}}
$$

In Equation (2), it is assumed that $\beta_{1}$ through $\beta_{4}$ are constant over individual counties and time. The error term, $\mathrm{u}_{\mathrm{it}}$, is assumed to be Gaussian, with mean zero and constant variance for all $i$ and $t$. The error terms of the counties are assumed to be uncorrelated for all $t$. These assumptions simplify estimation and are realistic, since the area is rather homogeneous.

In panel data literature, Equation (2) is a cell-mean corrected regression model. The model accounts for intercounty differences in the intercept coefficient, which is allowed to vary over counties, but not over time. Although the intercept varies over counties, all slope coefficients are assumed homogeneous over all counties. The technique is frequently employed in pooled data analyses because it provides a simple alternative to assuming that all parameters are homogeneous (Greene 1990, 483).

In estimating Equation (2), data for the sales tax differential and taxable sales were obtained from the Georgia and Florida Departments of Revenue. Personal income data were taken from the Survey of Current Business. Data for service and retail establishments calculations were obtained from Georgia Employment and Wages, 1980-89, and the Florida Statitical Abstracts, 1981- 
1990. The market area variable is calculated using the mean distance between neighboring cities of 10,000 or more. The data are annual for the period 1980-89.

The results from estimating Equation (2) are presented in Equation (3). The estimation technique involves expressing all variables as deviations from their cell- mean values, computed over the 10 years for each individual county, and using ordinary least squares (OLS) to estimate the transformed equation. Since positive autocorrelation was present when Equation (2) was estimated, the Cochrane-Orcutt procedure was used to correct for first-order serial correlation in the error term. Equation (3) presents the coefficient estimates with standard errors in parentheses below the coefficients.

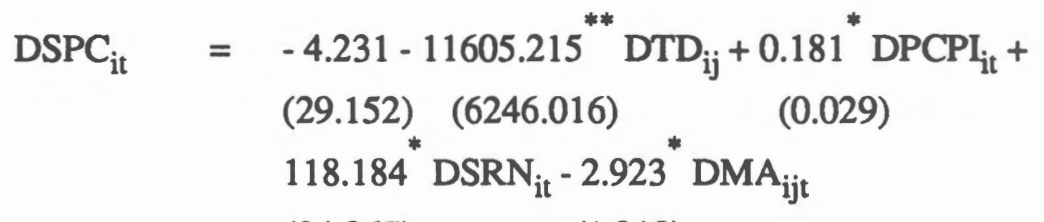

Adjusted $\mathrm{R}^{2}=.637, \mathrm{D} . \mathrm{W} .=1.818$, d.f. $=153$

*** Significant at the .05 level

Significant at the .05 level, one-tail test.

As expected, per capita personal income is directly and significantly related to per capita taxable sales. An increase in per capita income increases the per capita spending on taxable goods in the county. The number of retail establishments variable, which represents the urban county's attraction to consumers, is significant with the expected positive sign. As the number of retail establishments in an urban county increases, its attraction becomes greater and sales per capita increase. The market area variable, which reflects the attraction of competing urban counties and the travel cost to the ith urban county, is significant and inversely related to sales. An increase in the populations of competing urban counties would tend to draw away consumers and lower the county's sales per capita.

The variable of most interest in this study-the sales tax differential-is inversely related to taxable sales per capita in the urban counties and is significant at the .05 level, using a one-tail test. The differences in the sales tax rates between the urban counties and their contiguous counties appear to influence the level of per capita taxable sales, even though differentials are small. This result is similar to that found in previous border area, tax differential studies. However, the result 
differs in one important respect: previous studies that find the tax differential variable to be significant (Mikesell 1970; Fisher 1980; Walsh and Jones 1988) involve regions where alternative shopping facilities are readily available; the limited shopping alternatives case examined by Snodgrass and Otto (1990) resulted in a variable that is not statistically significant.

The elasticity coefficients for each of the 16 urban counties were calculated at their cell mean, and the estimates range from 1.09 to 3.92; therefore, a 1 percentage point increase in the sales tax is associated with a 1.79 percent decline in retail sales for the 16 areas over the historic range. This result indicates that taxable sales vary from unit elastic to highly elastic with respect to changes in the tax rate differential. An analysis of the relationships between the elasticity coefficients and urban county characteristics reveals that service/retail establishments per capita and distance to a city of comparable size are the most influential variables. The service/retail establishments per capita variable has a negative relationship with the absolute value of the elasticity coefficient, while distance is directly correlated with the coefficient. This finding implies that consumers consider the total costs in shopping decisions; they weigh the added cost of a tax against the cost of travel (distance) and search cost (service/retail establishments). Consumers do not react to changes in sales tax rates because the travel cost to more distant shopping centers and/or the search cost outweigh the increase in tax rates in the nearer urban county.

These results correspond favorably with those of the previous studies: Mikesell (1970), 1.69 to 10.97; Walsh and Jones (1988), 5.9; and Fisher (1980), 7.0. However, this study differs substantially from Snodgrass and Otto (1990), who found an elasticity coefficient between 10 and 11 . Snodgrass and Otto were unable to find a statistically significant relationship between the tax rate differential variable and tax revenues. However, they conclude: "Although the coefficient for tax differential is not significant in any specifications, the coefficients imply a very elastic response in local tax revenues. A one percent increase in the tax differential within a trade area, holding tax rates constant, suggests that tax revenues decline by 10 to 11 percent" $(1980,40)$. The variance in our findings may result from our specifications of alternative shopping areas. Snodgrass and Otto use the one-directional gravity effect of the nearest central city (25,000 population), while this study employs the average distance to contiguous cities of comparable size.

\section{CONCLUSIONS}

This study examines the impact of sales tax differentials on taxable sales in rural south Georgia during 1980-89. Results indicate that a differential in sales 
tax rates has a significant effect on an urban county's taxable sales. The level of impact on taxable sales, as measured by its elasticity coefficient, is influenced by the shopping characteristics of the area. A greater number of service and retail establishments tends to lessen the impact of a tax differential as search costs are reduced, while nearby shopping alternatives increase the effect as travel costs are reduced. These results have interesting implications for tax policy in rural south Georgia. The impact of creating a sales tax differential appears to depend on the shopping attributes of the urban county relative to its competing urban counties. In a rural environment where consumers have shopping pattems and lack convenient shopping alternatives, regional shopping centers have the potential to shift or export part of their tax burden without causing significant loss to their retail trading base.

The research presented here is concerned with the effects of sales tax differentials among taxing jurisdictions in a rural environment. Further research is needed to investigate the impact on sales per capita of differential patterns in demographic characteristics in the regions. In addition, the extent that rapid regional growth influences consumer response is important to policymakers.

\section{ENDNOTES}

1. South Georgia is defined here to mean south of the city of Macon. The study is limited to south Georgia because of the difference in population concentrations in the two regions. In 1990, 70 percent of the population in the north lived in MSAs, compared to 15 percent in the south.

2. The urban counties used in the study, along with their cities and populations, include:

\begin{tabular}{l} 
Urban County \\
\hline Sumter \\
Decatur \\
Glynn \\
Crisp \\
Laurens \\
Coffee \\
Ben Hill \\
Liberty \\
Wayne \\
Colquitt \\
Bulloch \\
Thomas \\
Tift \\
Lowndes \\
Toombs \\
Ware
\end{tabular}

City

Americus

Bainbridge

Brunswick

Cordele

Dublin

Douglas

Fitzgerald

Hinesville

Jesup

Moultrie

Statesboro

Thomasville

Tifton

Valdosta

Vidalia

Waycross
1989 City Population

16,000

11,000

20,000

11,000

17,000

11,000

10,000

17,000

10,000

16,000

16,000

19,000

14,000

36,000

12,000

19,000 


\section{REFERENCES}

Bureau of Economic and Business Research. Florida Statistical Abstract. Gainsville, Fla.: University of Florida, 1981-90.

Cooperative Extension Service. The Georgia County Guide. Athens, Ga.: University of Georgia, 1981-90.

Fisher, Ronald C. "Local Sales Taxes: Tax Rate Differentials, Sales Loss, and Revenue Estimation." Public Finance Quarterly 8 (1980): 171-188.

Fisher, Ronald C. State and Local Public Finance. Glenview, III: Scott, Foresman and Co., 1988.

Georgia Department of Labor. Georgia Employment and Wages. Atlanta, Ga., 1980-90.

Greene, William H. Econometric Analysis. New York: MacMillian Publishing Co., 1990.

Mikesell, John L. "Central City and Sales Tax Rate Differentials: The Border City Problem." National Tax Journal 23 (1970): 206-213.

Snodgrass, Dodd W., and Daniel M. Otto. "Analysis of Local Taxation in Rural Areas: An Oklahoma Case Study." Growth and Change 21(1990): 34-45.

U.S. Department of Commerce, Bureau of Economic Analysis. Survey of Current Business. Washington, D.C.: U.S. Government Printing Office, 1982-90.

Walsh, Michael J., and Jonathan D. Jones. "More Evidence on the 'Border Tax' Effect: The Case of West Virginia, 1979-84." National Tax Journal 41(1988): 591-601. 